\title{
Translating evidence into practice: Hong Kong Reference Framework for Preventive Care for Children in Primary Care Settings
}

\author{
Natalie PY Siu, LC Too, Caroline SH Tsang *, Betty WY Young
}

This article was published on 22 May 2015 at www.hkmj.org.

\section{A B S T R A C T}

There is increasing evidence that supports the close relationship between childhood and adult health. Fostering healthy growth and development of children deserves attention and effort. The Reference Framework for Preventive Care for Children in Primary Care Settings has been published by the Task Force on Conceptual Model and Preventive Protocols under the direction of the Working Group on Primary Care. It aims to promote health and prevent disease in children and is based on the latest research, and contributions of the Clinical Advisory Group that comprises primary care physicians, paediatricians, allied health professionals, and patient groups. This article highlights the comprehensive, continuing, and patient-centred preventive care for children and discusses how primary care physicians can incorporate the evidence-based recommendations into clinical practice. It is anticipated that the adoption of this framework will contribute to improved health and wellbeing of children.
Hong Kong Med J 2015;21:261-8
DOI: $10.12809 / \mathrm{hkmj} 144307$
${ }^{1}$ NPY Siu, MB, BS, FHKAM (Family Medicine)
${ }^{1}$ LC Too, MB, BS, FHKAM (Family Medicine)
${ }^{1}$ CSH Tsang *, MB, ChB, FHKAM (Community Medicine)
BWY Young, MB, BS, FHKAM (Paediatrics)

\begin{abstract}
Primary Care Office, Department of Health, Hong Kong
2 Clinical Advisory Group on Hong Kong Reference Framework for

Preventive Care for Children in Primary Care Settings, Hong Kong
\end{abstract}
* Corresponding author: caroline_tsang@dh.gov.hk

\section{Introduction}

Advances in socio-economic conditions and health care delivery have contributed to improvement in child health indices in Hong Kong. For example, the infant mortality rate in Hong Kong is low by world standards, decreasing from 9.7 per 1000 live births in 1981 to 1.5 in 2012. Various problems, however, continue to affect the health of Hong Kong children. For instance, the increasing trend of obesity among primary and secondary school children has become a major public health concern. ${ }^{1}$ Injury is also a significant cause of mortality and morbidity in children. Many of these problems can be prevented.

In order to adopt the life-course approach to chronic disease prevention and health promotion, the Task Force on Conceptual Model and Preventive Protocols under the Working Group on Primary Care has identified two age-group-specific preventive reference frameworks, one of which is the Reference Framework for Preventive Care for Children in Primary Care Settings. ${ }^{2}$ It was developed according to the latest research evidence and with the support of the Clinical Advisory Group that comprises primary care physicians, specialists such as paediatricians, allied health professionals, and patient groups.

Many medical professionals have difficulty assimilating rapidly evolving scientific evidence into their practice. The reference framework provides an interface between research and practice, and aims to support health care professionals to promote health and provide continuing and comprehensive care for children in the community. It consists of a core document supplemented by a series of modules that elaborate on the various domains relevant to child health. This article highlights a practical use of this reference framework to improve the delivery of preventive care to children in the primary care setting.

\section{Evidence-based preventive care for children}

The core document of the reference framework provides evidence-based recommendations for comprehensive preventive care for children and can be categorised into various health domains, ranging from prenatal care to care for children with special needs. Preventive care activities for children applicable to the primary care setting are summarised in Table 1.

\section{Continuing and patient-centred preventive care for children}

The commitment of primary care physicians to preventive care of children is vital in the prevention of disease as well as early detection of problems and appropriate intervention. Every encounter with a child and/or the parents/caregivers should be an 
由實證到實踐：《香港兒童護理參考概覽 兒童在基層醫療的預防護理》

蕭珮儀、陶麗莊、曾守衡、楊允賢

越來越多證據顯示童年時期的健康狀況與成年後的健康狀況關係密 切。因此, 關注並竭力確保兒童的健康成長和發展十分重要。基層醫 療工作小組轄下的基層醫療概念模式及預防工作常規專責小組編製了 《香港兒童護理參考概覽一一兒童在基層醫療的預防護理》。這概覽 是由家庭醫生、兒科專科醫生、專職醫療人員及病人組織組成的臨床 諮詢小組以最新的實證編製而成的。本文强調全面、持續及以人為本 的兒童預防護理, 並討論家庭醫生如何於臨床工作實踐以實證為本的 建議。我們相信採納此參考概覽能提昇兒童的健康。 opportunity to promote healthy practices. Some forms of prevention should be delivered regularly, for example, vaccinations that should adhere to the locally recommended schedule. Other preventive care may be offered opportunistically, such as advice on dental care and physical activity. It is neither possible nor appropriate to initiate all preventive care at a single clinic visit. Nevertheless the longterm relationship between primary care physicians and patients allows provision of comprehensive and continuing care.

\section{Practising preventive care for children in primary care}

Primary care physicians may not have adequate time to go through the reference framework, especially in a busy clinic setting. It is nonetheless necessary to establish how recommendations of the reference framework can be applied to patient care. Four practical tips on application of the reference framework will be discussed below.

\section{Make use of the two-page summary}

The Primary Care Office has developed a twopage summary that can be downloaded from its website (Fig 1). Tabulating the various preventive activities according to age-group will enable primary care physicians to provide suitable age-specific preventive measures for their patients. The relevant chapter of the core document is identified for each aspect of preventive care, informing the primary care physician of where to find further information and supporting evidence. A summary can be posted on walls or on the desk in primary care consultation rooms to allow quick reference.

\section{Make use of patient-education materials}

Patient-based education interventions, especially those that involve patient-education material, have been reported to be effective in the implementation of clinical practice guidelines. ${ }^{3}$ Patient-education materials can also help more effectively deliver preventive advice. Resources related to the health care of children, such as transitional feeding (Table 2 ) and oral health (Table 3), are listed in annex 3 of the core document. A link to these resources can be accessed from the electronic version of the core document. These can be introduced to children and parents and enhance patient education.

\section{Record preventive care activities using checklists}

Embedding guideline evidence into the processes and documents of patient care can help promote established evidence-based recommendations. ${ }^{4}$ Checklists of opportunistic preventive care can also be incorporated in patient medical records to allow clear documentation and facilitate any followup care. Primary care physicians can prepare their own checklists or utilise the ready-made checklists available in chapter 8 of the Module on Immunisation (Fig 2).

\section{Deliver preventive care according to life stage}

Childhood can be considered a sequence of life stages, namely prenatal, infancy, preschool, school age, and adolescence. Among the recommendations in Table 1 , some items have particular relevance to particular life stages. For the care of an individual child in the primary care setting, preventive activities should be appropriate for age, risk status, and individual needs and values. Chapter 6 of the core document contains tables of preventive care for different life stages, and specifies the timing and action of various activities. Such a tailored approach to recommendations may ensure that the research-based message is more easily translated. ${ }^{5}$ The practice of preventive care for different life stages in daily practice can be illustrated as follows.

\section{Prenatal care}

Prenatal care is essential for a healthy outcome of pregnancy and should commence prior to conception. All women planning pregnancy should take daily folic acid supplement at a dose of $400 \mu \mathrm{g} /$ day for at least 1 month before conception, and continue through the first trimester to reduce the risk of having a baby with neural tube defect. ${ }^{6,7}$ If the history of vaccination or infection is uncertain, the woman should be screened for rubella susceptibility and, if indicated, rubella vaccine administered 3 months before conception. Influenza vaccination should also be offered. ${ }^{8}$ In addition, screening for hepatitis B virus, human immunodeficiency virus, and syphilis infections should be offered if it has not 
TABLE I. Recommended preventive care for children in primary care settings

\begin{tabular}{ll}
\hline Recommended preventive care \\
\hline Prenatal care & Provide prenatal care in collaboration with other prenatal care providers: \\
& - Screen for rubella susceptibility if previous history of vaccination or infection is uncertain \\
- Screen for hepatitis B virus, HIV, and syphilis infections & - Offer counselling and carrier testing for thalassaemia \\
& - Recommend influenza vaccination \\
- Advise folic acid supplement at least 1 month before conception and continue through the first & trimester \\
- Advise against use of tobacco, alcohol, and illicit drugs & - Promote breastfeeding \\
- Make enquiry about maternal depressive symptoms & - Promote skin-to-skin contact at birth
\end{tabular}

Immunisation

Nutrition

Physical activity

- Advocate and provide childhood immunisations according to recommended schedule. The Hong Kong Childhood Immunisation Programme is shown in the Appendix for reference

- Promote and support exclusive breastfeeding in the first 6 months of life

- Advise proper use of infant formula when breast milk cannot be offered

- Advise introduction of solid foods and transitional feeding from around 6 months of age

- Advise children aged $\geq 2$ years to adopt a diet that primarily relies on whole grains, fruits and vegetables, low-fat or non-fat dairy products, legumes, fish, and lean meat

- Advise children of preschool age who are capable of walking unaided to accumulate at least 3 hours of physical activity each day

- Advise children and youth aged 5-17 years to accumulate an average of at least 60 minutes and up to several hours of at-least-moderate-intensity physical activity per day. Moderate-intensity activity could be expressed as a level of effort of 5 or 6 on a scale of 0 to 10 (where 0 is the level of effort of sitting, and 10 is maximal effort) or $50-70 \%$ of maximum heart rate

- Advise to avoid screen time for children $<2$ years and limit total screen time for children $>2$ years to no more than 2 hours per day

- Advise to avoid any sedentary activity lasting $>1$ hour for preschool children

Dental care

- Advise brushing teeth twice a day with toothpaste containing 1000 ppm fluoride in children aged 2-6 years and with toothpaste containing 1000-1500 ppm fluoride in children $>6$ years

- Deliver dental and oral health counselling and education messages

Visual health

- Encourage children to increase the amount of outdoor activities

- Deliver counselling and education messages on visual hygiene

Promote safe and healthy behaviours - Encourage and assist parents who smoke to quit smoking

- Advise measures to prevent injury and sudden infant death syndrome

- Help adolescents abstain from tobacco, alcohol, and illicit drugs

- Deliver sexual health counselling to adolescents

Promote mental and psychosocial wellbeing

- Encourage family meals

- Offer counselling on proper use of media and limited screen time

- Promote development of positive psychological and emotional lifestyle and life skills

Family relationship, parenting, and social wellbeing

- Assess mental and psychosocial wellbeing of parents and offer necessary help and support

- Help parents develop secure and positive attachments with their children. Promote age-appropriate positive parenting practices

- Encourage age-appropriate play

Identification of growth problems

- Perform serial measurements of weight and height

- Screen children aged $\geq 6$ years for obesity and offer appropriate interventions or referral to promote improvements in weight status

Identification of developmental problems

- Screen for hearing loss in all newborn infants

- Screen for vision problems for all children at least once between the ages of 3 and 5 years, to detect the presence of amblyopia or its risk factors

- Systematically elicit parental concerns. Perform developmental surveillance in collaboration with caregivers and schools

Identification of mental, psychological, • Evaluate for attention-deficit hyperactivity disorder for any children aged 4-18 years who present with behavioural, and social problems suggestive symptoms

- Identify children and adolescents with psychological or mental disorders such as anxiety disorders and eating disorders. Offer appropriate management and refer as necessary

- Consider family and social problems in children and adolescents presenting with mental or psychological symptoms

- Screen for major depressive disorders in adolescents

Care for children with disabilities

- Identify the special needs of children with disability and their families and offer support tailored to them

- Serve as service and health care coordinators and advocates for the welfare and benefits of children with disabilities and their families

Empowering parents/carers in

- Give information and specific advice to carers in the management of acute diseases of children $\begin{aligned} & \text { management of common diseases of } \\ & \text { children }\end{aligned}$
sense of control
snvolve parents and children in the management of childhood chronic diseases and help them acquire a Abbreviation: HIV = human immunodeficiency virus 
Hong Kong Reference Framework for Preventive Care for Children in Primary Care Settings Perform the following evidence-based recommendations on preventive activities for children in your clinics

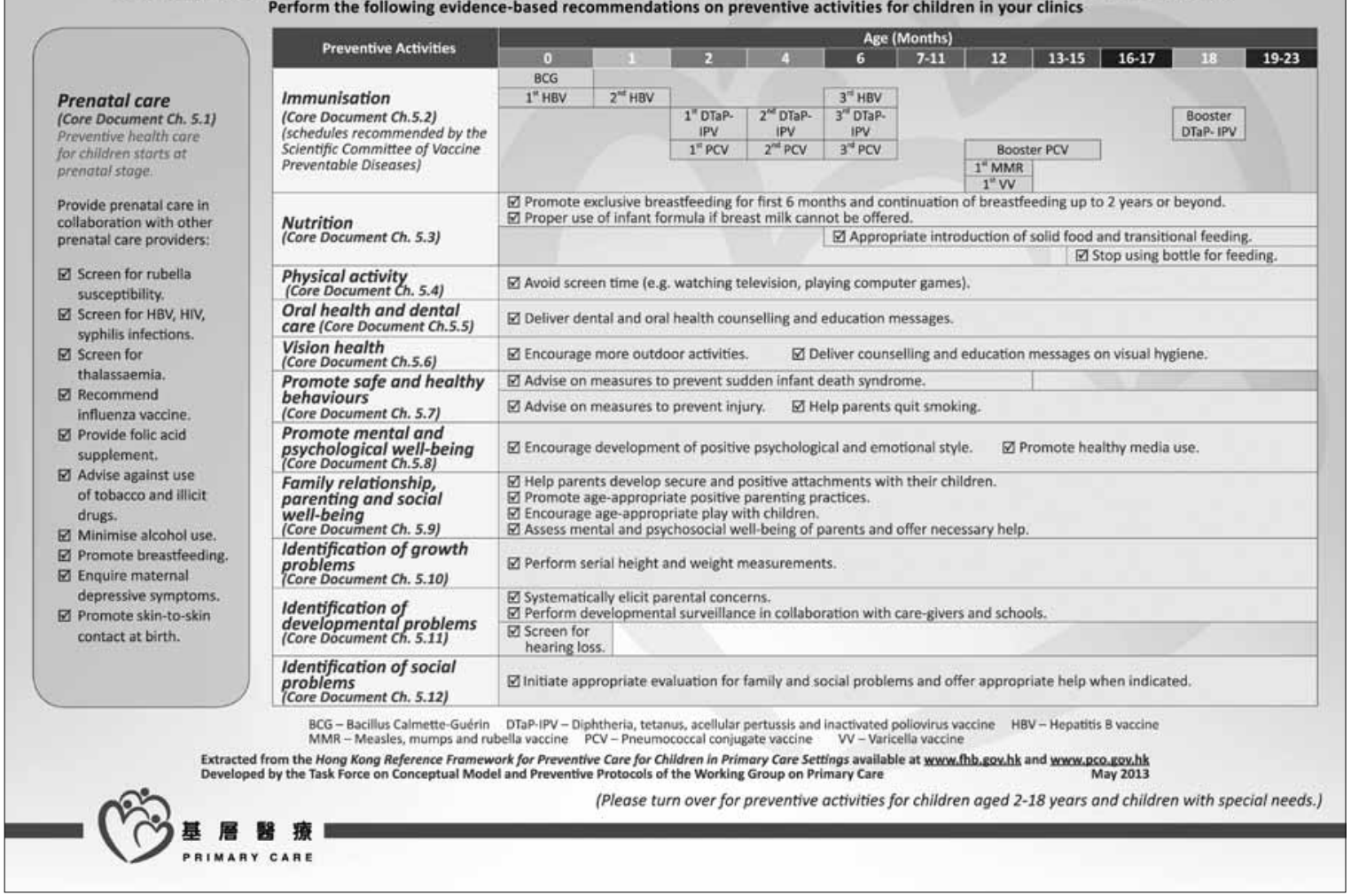

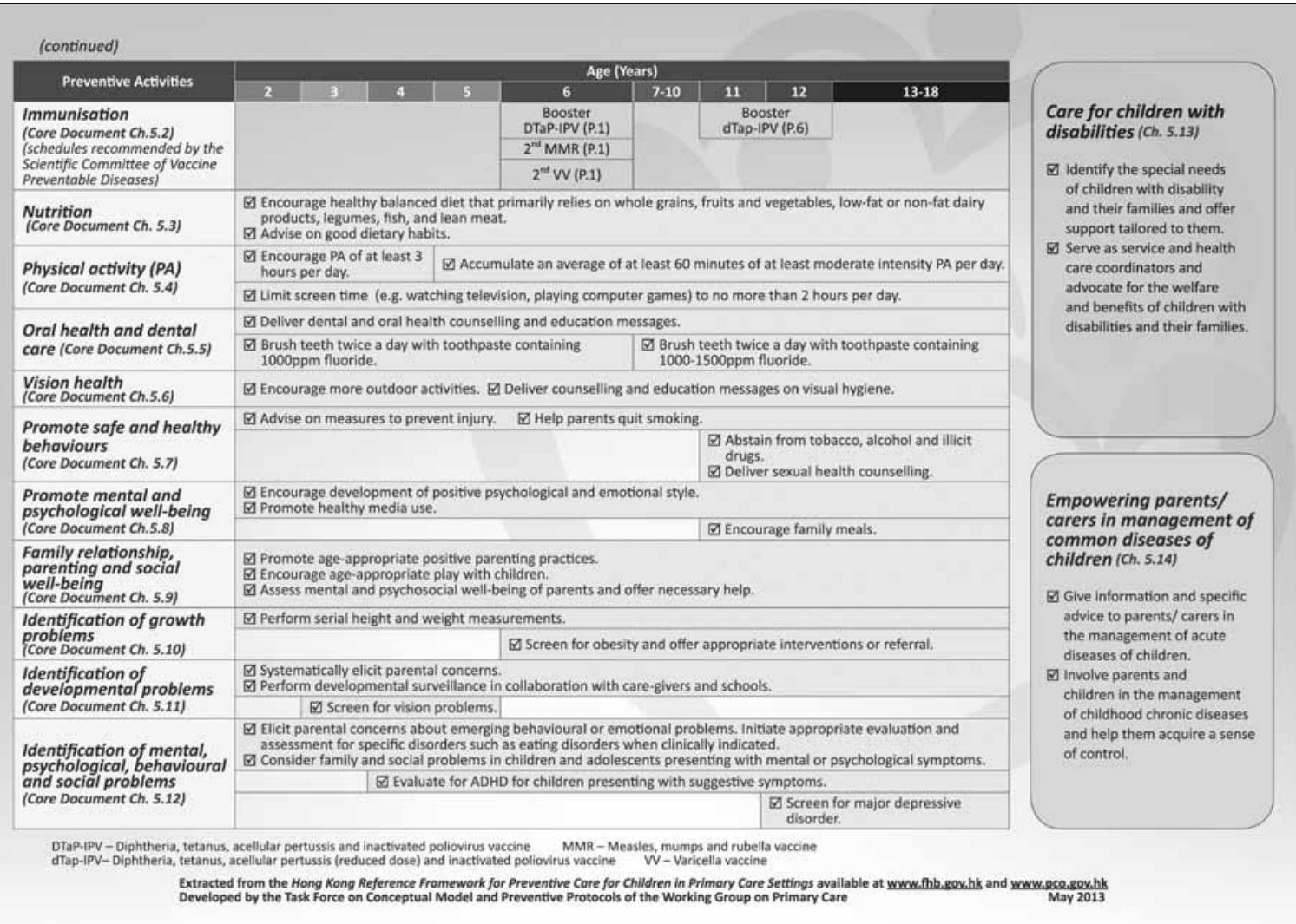

FIG I. Two-page summary of the Hong Kong Reference Framework for Preventive Care for Children in Primary Care Settings 
TABLE 2. Resources on transitional feeding for children aged 6-24 months

\begin{tabular}{lll}
\hline Organisation & Resource & Website \\
\hline $\begin{array}{l}\text { Department of Health, } \\
\text { Family Health Service }\end{array}$ & $\begin{array}{l}\text { Healthy eating for 6- to 24-month-old } \\
\text { children (1) [getting started] }\end{array}$ & $\begin{array}{l}\text { http://www.fhs.gov.hk/english/health_info/child/14727.html (English) } \\
\text { http://www.fhs.gov.hk/tc_chi/health_info/child/14727.html (Chinese) }\end{array}$ \\
& $\begin{array}{l}\text { Healthy eating for 6- to 24-month-old } \\
\text { children (2) [moving on] }\end{array}$ & $\begin{array}{l}\text { http://www.fhs.gov.hk/english/health_info/child/14722/index.html (English) } \\
\text { http://www.fhs.gov.hk/tc_chi/health_info/child/14722/index.html (Chinese) }\end{array}$ \\
& $\begin{array}{l}\text { 7-Day healthy meal planning guide for 6- to http://www.fhs.gov.hk/english/health_info/child/14732/index.html } \\
\text { 24-month-old children }\end{array}$ \\
\hline
\end{tabular}

TABLE 3. Resources on oral health

\begin{tabular}{|c|c|c|}
\hline Organisation & Resource & Website \\
\hline $\begin{array}{l}\text { Department of Health, } \\
\text { Family Health Service }\end{array}$ & Family Health Service website & $\begin{array}{l}\text { http://www.fhs.gov.hk/english/health_info/class_topic/ct_child_health/ } \\
\text { ch_oral_health.html }\end{array}$ \\
\hline \multirow[t]{4}{*}{$\begin{array}{l}\text { Department of Health, Oral } \\
\text { Health Education Unit }\end{array}$} & $\begin{array}{l}\text { Oral Health Education Unit website } \\
\text { leaflets }\end{array}$ & http://www.toothclub.gov.hk/en/en_home_01_01_01.html \\
\hline & Brushing teeth is what children can do & $\begin{array}{l}\text { http://www.toothclub.gov.hk/en/en_pdf/en_B005.pdf (English) } \\
\text { http://www.toothclub.gov.hk/chi/pdf/booklet_pdf/B005.pdf (Chinese) }\end{array}$ \\
\hline & Children's diet and dental health & $\begin{array}{l}\text { http://www.toothclub.gov.hk/en/en_pdf/en_B019_05.pdf (English) } \\
\text { http://www.toothclub.gov.hk/chi/pdf/booklet_pdf/B019_05.pdf (Chinese) }\end{array}$ \\
\hline & $\begin{array}{l}\text { Oral health care for your children (for } \\
\text { children aged 0-6 years) }\end{array}$ & $\begin{array}{l}\text { http://www.toothclub.gov.hk/en/en_pdf/en_B054.pdf (English) } \\
\text { http://www.toothclub.gov.hk/chi/pdf/booklet_pdf/B033.pdf (Chinese) }\end{array}$ \\
\hline
\end{tabular}

been performed..$^{9-11}$

Due to their harmful effect on fetal growth and development, women should be questioned about tobacco and alcohol use, and appropriate counselling offered. ${ }^{12,13}$ Breastfeeding should be promoted with relevant education and support commencing prenatally. ${ }^{14,15}$

\section{Infancy (0-24 months of age)}

Children and families experience rapid changes during the period of infancy. Immunisation for various infectious diseases is vital at this stage. Each visit of a child to their primary care physician provides an opportunity to confirm that immunisations are up to date. Other advice on preventive care can also be given at the same time, such as promotion of breastfeeding. Primary care providers can refer to the core document for strategies to promote breastfeeding and the principles of transitional feeding.

The long-term relationship between primary care physicians and families allows for surveillance of a child's growth and development. Serial measurements of the weight and length of an infant should be recorded on a population-specific growth chart. Routine screening for hearing loss should also be arranged.

Visits to the primary care physician's clinic provide an opportunity to observe relationships between parents and their children. Secure parent-child attachment in early childhood can be protective and provide a foundation for exploration and normal development. ${ }^{16}$ Parents can be helped to understand the concept of attachment and develop appropriate responses to the attachment behaviours of their young children. Parents' psychosocial wellbeing and parenting capacity should be monitored and assistance given when indicated.

\section{Preschool (2-5 years of age)}

Young children should be provided with a balanced diet that comprises grains and cereals, vegetables and meat (including its alternatives, eg fish, poultry, eggs, beans, etc) in a ratio of 3:2:1 by volume. ${ }^{17}$

Ongoing surveillance of growth, and physical and psychosocial development should be undertaken in partnership with parents. Screening for vision problems should be offered for all children aged between 3 and 5 years to detect amblyopia or the presence of any risk for its development. Any parental concerns about a child's development such as hearing, language, gross and fine motor development, and social behaviours should be elicited systematically. Updating a child's developmental history by direct questioning of a parent or carer can assist in the identification of any abnormalities that warrant further investigation. Parents should also be asked if they have any concerns about their child's behaviour. Testing for attentiondeficit/hyperactivity disorder should be initiated if academic or behavioural problems and symptoms of inattention, hyperactivity, or impulsivity are present. Parenting programmes have been shown to 


\begin{tabular}{|c|c|c|c|c|c|c|}
\hline & & Birth & 1 month & 2 months & 4 months & 6 months \\
\hline \multirow{5}{*}{\multicolumn{2}{|c|}{$\begin{array}{l}\text { Age-appropriate } \\
\text { Immunisations } \\
\text { ("schedule recommended by the } \\
\text { Scientific Committee of Vaccine } \\
\text { Preventable Diseases) }\end{array}$}} & $\square$ BCG* & & & & \\
\hline & & $\square \mathrm{HBV}^{*}$ & $\square \mathrm{HBV}^{*}$ & & & $\square \mathrm{HBV}^{*}$ \\
\hline & & & & $\square$ DTaP-IPV* & $\square$ DTaP-IPV* & $\square$ DTaP-IPV* \\
\hline & & & & $\square \mathrm{PCV}^{*}$ & $\square \mathrm{PCV}^{*}$ & $\square \mathrm{PCV}^{*}$ \\
\hline & & & & & & $\square$ Influenza ** \\
\hline \multicolumn{2}{|c|}{ Other immunisations } & & & $\bar{\square}$ & $\square \quad \square \quad$ & 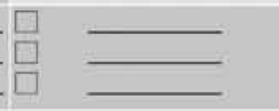 \\
\hline \multicolumn{7}{|c|}{ Development } \\
\hline 1 & Gross and fine motor & $\begin{array}{l}\square \text { Spontaneous } \\
\text { and symmetrical } \\
\text { movements of } 4 \\
\text { limbs } \\
\text { Hip examination }\end{array}$ & $\begin{array}{l}\square \text { Keep head in } \\
\text { midline when } \\
\text { lie supine } \\
\square \text { Opens hands } \\
\text { occasionally }\end{array}$ & $\begin{array}{l}\square \text { Raises head } \\
\text { about } 30^{\circ} \text { in } \\
\text { prone position } \\
\square \text { Starts hand } \\
\text { regards }\end{array}$ & $\begin{array}{l}\square \text { Holds head } \\
\text { steadily } \\
\text { in upright } \\
\text { position } \\
\square \text { Grasps hand } \\
\text { toys }\end{array}$ & $\begin{array}{l}\text { Rolls over } \\
\text { Sit with support }\end{array}$ \\
\hline 2 & $\begin{array}{l}\text { Communication/ } \\
\text { language }\end{array}$ & $\begin{array}{l}\square \text { Cries to indicate } \\
\text { needs }\end{array}$ & $\begin{array}{l}\text { Responsive to } \\
\text { calming actions } \\
\text { when upset }\end{array}$ & $\begin{array}{l}\square \text { Starts making } \\
\text { some cooing } \\
\text { sound }\end{array}$ & $\square$ cooing & $\begin{array}{l}\square \text { Responds to own name } \\
\text { Babbling }\end{array}$ \\
\hline 3 & Social behavior & & \begin{tabular}{|l|}
$\square$ Brief eye \\
contact \\
$\square$ Social responsive \\
smile \\
\end{tabular} & 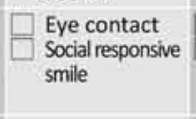 & \begin{tabular}{|l|} 
\\
Turn taking \\
Laughs out \\
loud when \\
played with
\end{tabular} & $\begin{array}{l}\square \text { Recognises familiar } \\
\text { faces }\end{array}$ \\
\hline 4 & Cognitive & & & & $\begin{array}{l}\square \text { Shakes toys } \\
\text { to make } \\
\text { sound }\end{array}$ & $\square$ Looks for falling objects \\
\hline 5 & Hearing & $\begin{array}{l}\square \text { Newborn hearing } \\
\text { screening } \\
\square \text { Startle with noise }\end{array}$ & $\begin{array}{l}\square \text { Quiet on } \\
\text { hearing } \\
\text { mother's } \\
\text { voice }\end{array}$ & $\begin{array}{l}\text { Quiet on } \\
\text { hearing } \\
\text { mother's } \\
\text { voice }\end{array}$ & $\begin{array}{l}\square \text { Turns head } \\
\text { to sound/ } \\
\text { human } \\
\text { voice }\end{array}$ & $\begin{array}{l}\square \text { Localises source of } \\
\text { sound }\end{array}$ \\
\hline 6 & Vision & $\square$ Screen for red reflex & $\begin{array}{l}\text { Transiently } \\
\text { follows the face } \\
\text { approaching } \\
\text { closely }\end{array}$ & $\begin{array}{l}\text { Follows object } \\
\text { with eyes }\end{array}$ & $\begin{array}{l}\square \text { Follows objects } \\
\text { horizontally } \\
\text { across midline } \\
\text { with eyes }\end{array}$ & $\begin{array}{l}\square \text { Follows objects in all } \\
\text { direction }\end{array}$ \\
\hline 7 & Specific parental concem & & & & & \\
\hline \multicolumn{7}{|c|}{ Growth monitoring } \\
\hline & & Weight / percentile & Weight/percentile & $\overline{\text { Weight / percentile }}$ & Weight/percentile & Weight / percentile \\
\hline & & Length / percentile & Length / percentile & Length / percentile & Length/percentile & Length / percentile \\
\hline & & Head circumference & $\overline{\text { Head circumference }}$ & Head circumference & Head dirumference & Head circumference \\
\hline \multirow{3}{*}{\multicolumn{2}{|c|}{ Nutrition and feeding }} & $\begin{array}{l}\text { Feeding history: } \\
\square \text { Milk: }\end{array}$ & $\begin{array}{l}\text { Feeding history: } \\
\square \text { Milk: }\end{array}$ & $\begin{array}{l}\text { Feeding history: } \\
\square \text { Milk: }\end{array}$ & $\begin{array}{l}\text { Feeding history: } \\
\square \text { Milk: }\end{array}$ & $\begin{array}{l}\text { Feeding history: } \\
\square \text { Milk } \\
\square \text { Solid food }\end{array}$ \\
\hline & & \multicolumn{5}{|c|}{$\square$ Promote exclusive breastfeeding and advise proper use of infant formula if not breastfed } \\
\hline & & & & & \multicolumn{2}{|c|}{$\begin{array}{l}\square \text { Give anticipatory guidance on introduction } \\
\text { of solid food and transitional feeding }\end{array}$} \\
\hline \multirow{2}{*}{\multicolumn{2}{|c|}{ Opportunistic guidance and advice }} & \multicolumn{5}{|c|}{$\begin{array}{l}\text { Advise on oral and dental care } \\
\text { Advise on measures to prevent sudden infant death syndrome and injuries } \\
\text { Encourage and assist parents who smoke to quit smoking } \\
\text { Encourage to develop secure parent-child attachment and provide a safe, secure and loving environment } \\
\text { Discourage screen time } \\
\text { Promote age-appropriate positive parenting practices } \\
\text { Encourage parents to play with their children } \\
\text { Assess mental and psychosocial well-being of parents and offer help if necessary } \\
\text { Enquire about maternal depressive symptoms }\end{array}$} \\
\hline & & Visit date & Visit date & Visit date & Visit date & Visit date \\
\hline
\end{tabular}

${ }^{* *} A$ 2-dose regimen separated by at least 28 days for vaccine naïve children below 9 years. Children below 9 years who have properly received one or more doses of seasonal influenza vaccine in any previous season are recommended to receive one dose in the current season.

"** The Government is providing subsidised seasonal influenza vaccination under the Childhood Influenza Vaccination Subsidy Scheme to Hong Kong children aged between 6 months and less than 6 years or those attending a kindergarten or child care centre in Hong Kong. Some children may also be eligible for free seasonal influenza vaccination under Government Vaccination Programme.

$\uparrow$ Reference from the Developmental Surveillance Scheme of the Family Health Service, Department of Health.

FIG 2. One of the checklists of immunisation and opportunistic preventive care from the Module on Immunisation 
improve both child behaviour and parenting. ${ }^{18-22}$ As such, they should be promoted to parents.

Toddlers are prone to injury as they are active and love to explore their environment. Parents can be given advice on how to maintain a safe environment and prevent accidental injury. ${ }^{23}$

\section{School age (6-12 years of age)}

As children grow up, they can be expected to take on additional responsibility for their health. Healthy lifestyle advice, such as eating a healthy balanced diet and taking adequate physical activity, can be discussed during clinical consultations for episodic illnesses. It is recommended that children aged 5 years and above be involved in at least 60 minutes of moderate-to-vigorous-intensity physical activity each day. ${ }^{24-26}$ Children should minimise sedentary activity and avoid screen time of more than 2 hours per day. ${ }^{27-29}$ Differences can be observed in physical growth among children in this life stage. Screening for obesity can be offered for children aged 6 years and older, and appropriate weight maintained by counselling and behavioural intervention where indicated. ${ }^{30}$

School age is the time when learning difficulties or behavioural problems start to manifest. Primary care physicians can ask parents about progress at school and academic performance. Poor school performance may indicate an underlying learning or attention disorder. Children should be referred for detailed assessment if specific learning disabilities are suspected.

\section{Adolescence (13-18 years of age)}

Adolescence is the key transition stage between childhood and adulthood, a stage of attaining physical and sexual maturity. Adolescents are curious about new things and can be subject to peer pressure with consequent engagement in risk behaviour. When primary care physicians encounter adolescents, they have an opportunity to explore their psychosocial wellbeing. Information can be obtained about social life and extracurricular activities. Healthy activities such as sports and outdoor activities and healthy use of the mass media can be promoted as appropriate. If adolescents express boredom and loss of interest in their usual activities, depression should be suspected. Screening for a major depressive disorder can be conducted when systems are in place to ensure accurate diagnosis, psychotherapy, and follow-up. ${ }^{31}$

Smoking status for all teenagers should be established whenever the opportunity arises. Use of alcohol and illicit drugs should also be assessed using a non-judgemental approach. Adolescents who abuse either should be assisted to quit and referred for further management. ${ }^{32,33}$ Sexual history can be obtained and preventive counselling on sexual health issues delivered. ${ }^{34}$ High-intensity behavioural counselling is recommended to prevent sexually transmitted infections in all sexually active adolescents considered to be at increased risk.

Adolescents and their families should be encouraged to eat together: frequency of family meals has been inversely associated with poor academic performance, depressive symptoms, and risky behaviour such as tobacco and alcohol use. ${ }^{35}$

\section{Conclusion}

Chronic disease prevention and health promotion can begin in childhood. Effective delivery of preventive care to children depends on the combined efforts of health care professionals, social workers, teachers, and parents. Through provision of patient-centred, comprehensive, continuing and coordinated care, primary care physicians play a vital role in preventive care for children. The reference framework provides a common reference and guidance on a spectrum of preventive care activities for children. Adoption of the reference framework, its accompanying two-page summary, patient-education materials, and preventive care checklist enhances delivery of care. Practice of age-appropriate preventive care in different life stages can improve the health and wellbeing of children. Primary care physicians are in a privileged position to incorporate recommendations of the reference framework into clinical practice, and they are encouraged to familiarise themselves with the content of the reference framework. Development of new modules is underway to provide practical tips and information about topical issues already featured in the core document of the reference framework. Health care professionals are encouraged to visit the website of the Primary Care Office at $<w w w$. pco.gov.hk > and watch out for the new modules to be released, as well as information about seminars related to introduction of the reference frameworks. Feedback about implementation of the framework is welcome and will be valuable for revision of the core document and development of future modules.

\section{Appendix}

Additional material related to this article can be found on the HKMJ website. Please go to <http:// www.hkmj.org>, and search for the article.

\section{References}

1. Student Health Service. Newsletter [Internet]. December 2012; 57. Hong Kong SAR: Department of Health. Available from: http://www.studenthealth.gov.hk/english/ newsletters/newsletter_57.html. Accessed 18 Mar 2015.

2. Hong Kong reference framework for preventive care for children in primary care settings 2012. Available from: http://www.pco.gov.hk/english/resource/files/ref_ framework_children.pdf. Accessed 13 Nov 2014. 
3. Davis DA, Taylor-Vaisey A. Translating guidelines into practice. A systematic review of theoretic concepts, practical experience and research evidence in the adoption of clinical practice guidelines. CMAJ 1997;157:408-16.

4. Gerhardt WE, Schoettker PJ, Donovan EF, Kotagal UR, Muething SE. Putting evidence-based clinical practice guidelines into practice: an academic pediatric center's experience. Jt Comm J Qual Patient Saf 2007;33:226-35.

5. Yana R, Jo RM. Getting guidelines into practice: a literature review. Nurs Stand 2004;18:33-40.

6. Blencowe H, Cousens S, Modell B, Lawn J. Folic acid to reduce neonatal mortality from neural tube disorders. Int J Epidemiol 2010;39(Suppl 1):i110-21.

7. Wolff T, Witkop CT, Miller T, Syed SB; U.S. Preventive Services Task Force. Folic acid supplementation for the prevention of neural tube defects: an update of the evidence for the U.S. Preventive Services Task Force. Ann Intern Med 2009;150:632-9.

8. National Center for Immunization and Respiratory Diseases. General recommendations on immunizationrecommendations of the Advisory Committee on Immunization Practices (ACIP). MMWR Recomm Rep 2011;60:26-7

9. Wong VC, Ip HM, Reesink HW, et al. Prevention of the HBsAg carrier state in newborn infants of mothers who are chronic carriers of HBsAg and $\mathrm{HBeAg}$ by administration of hepatitis-B vaccine and hepatitis-B immunoglobulin. Double-blind randomised placebo-controlled study. Lancet 1984;1:921-6.

10. Chou R, Smits AK, Huffman LH, Fu R, Korthuis PT; US Preventive Services Task Force. Prenatal screening for HIV: A review of the evidence for the U.S. Preventive Services Task Force. Ann Intern Med 2005;143:38-54.

11. Wolff T, Shelton E, Sessions C, Miller T. Screening for syphilis infection in pregnant women: evidence for the U.S. Preventive Services Task Force reaffirmation recommendation statement. Ann Intern Med 2009;150:710-6

12. Lumley J, Chamberlain C, Dowswell T, Oliver S, Oakley $\mathrm{L}$, Watson L. Interventions for promoting smoking cessation during pregnancy. Cochrane Database Syst Rev 2009;(3):CD001055.

13. Whitlock EP, Polen MR, Green CA, Orleans T, Klein J; U.S. Preventive Services Task Force. Behavioral counseling interventions in primary care to reduce risky/harmful alcohol use by adults: a summary of the evidence for the U.S. Preventive Services Task Force. Ann Intern Med 2004;140:557-68.

14. Britton C, McCormick FM, Renfrew MJ, Wade A, King SE. Support for breastfeeding mothers. Cochrane Database Syst Rev 2007;(1):CD001141.

15. Chung M, Raman G, Trikalinos T, Lau J, Ip S. Interventions in primary care to promote breastfeeding: an evidence review for the U.S. Preventive Services Task Force. Ann Intern Med 2008;149:565-82.

16. Greenberg MT, Speltz ML, DeKlyen M. The role of attachment in the early development of disruptive behavior problems. Dev Psychopathol 1993;5:191-213.

17. Department of Health, HKSARG. The healthy eating food pyramid-a guide to a balanced diet. Available from: http:// www.cheu.gov.hk/eng/info/2plus3_12.htm. Accessed Mar 2015 .

18. Thomas R, Zimmer-Gembeck MJ. Behavioral outcomes of Parent-Child Interaction Therapy and Triple P-Positive
Parenting Program: a review and meta-analysis. J Abnorm Child Psychol 2007;35:475-95.

19. Nowak C, Heinrichs N. A comprehensive meta-analysis of Triple P-Positive Parenting Program using hierarchical linear modeling: effectiveness and moderating variables. Clin Child Fam Psychol Rev 2008;11:114-44.

20. de Graaf I, Speetjens P, Smit F, de Wolff M, Tavecchio L. Effectiveness of the Triple P Positive Parenting Program on behavioral problems in children: a meta-analysis. Behav Modif 2008;32:714-35.

21. Effective strategies to support positive parenting in community health centers: Report of the Working Group on Child Maltreatment Prevention in Community Health Centers. Washington, DC: American Psychological Association; 2009

22. Centre for Excellence and Outcomes in Children and Young People's Services. Improving children's outcomes by supporting parental physical and mental health. London: Department for Education; 2011.

23. Clamp M, Kendrick D. A randomised controlled trial of general practitioner safety advice for families with children under 5 years. BMJ 1998;316:1576-9.

24. Physical Activity Guidelines Advisory Committee Report. Washington, DC: US Department of Health and Human Services; 2008.

25. Global Recommendations on Physical Activity for Health. Geneva: World Health Organization; 2010.

26. Janssen I, Leblanc AG. Systematic review of the health benefits of physical activity and fitness in school-aged children and youth. Int J Behav Nutr Phys Act 2010;7:40.

27. Get up \& grow: healthy eating and physical activity for early childhood. Australia: Department of Health and Aging; 2009. Available from: http://www.health.gov.au/ internet/publications/publishing.nsf/Content/gug-carertoc. Accessed Mar 2015.

28. UK physical activity guideline. UK Department of Health. Available from: http:// www.dh.gov.uk/en/Publicationsandstatistics/Publications/ PublicationsPolicyAndGuidance/DH_127931. Accessed Mar 2015.

29. Guidelines for Preventive Activities in General Practice. 7th ed. The Royal Australian College of General Practitioners; 2009.

30. US Preventive Services Task Force, Barton M. Screening for obesity in children and adolescents: US Preventive Services Task Force recommendation statement. Pediatrics 2010;125:361-7.

31. Williams SB, O'Connor EA, Eder M, Whitlock EP. Screening for child and adolescent depression in primary care settings: a systematic evidence review for the US Preventive Services Task Force. Pediatrics 2009;123:e71635.

32. Supporting smoking cessation: a guide for health professionals. South Melbourne: The Royal Australian College of General Practitioners; 2011.

33. American Academy of Pediatrics: Committee on Substance Abuse. Alcohol use and abuse: a pediatric concern. Pediatrics 2001;108:185-9.

34. Preventive services for children and adolescents. 16th ed. Institute for Clinical Systems Improvement; 2010.

35. Eisenberg ME, Olson RE, Neumark-Sztainer D, Story M, Bearinger LH. Correlations between family meals and psychosocial well-being among adolescents. Arch Pediatr Adolesc Med 2004;158:792-6. 